\title{
The Association Between Major Dietary Patterns and Severe Mental Disorders Among a Large Sample of Adults Living in Central Iran: Baseline Data of YaHS-TAMYZ Cohort Study
}

\author{
Shamim Shams-Rad \\ Shahid Sadoughi University of Medical Sciences and Health Services \\ Reza Bidaki \\ Shahid Sadoughi University of Medical Sciences and Health Services \\ Azadeh Nadjarzadeh \\ Shahid Sadoughi University of Medical Sciences and Health Services \\ Masoud Mirzaei \\ Shahid Sadoughi University of Medical Sciences and Health Services \\ Amin Salehi-Abargouei ( $\square$ abargouei@gmail.com ) \\ Shahid Sadoughi University of Medical Sciences and Health Services https://orcid.org/0000-0002-7580-6717
}

\section{Research article}

Keywords: Dietary patterns, Severe Mental Disorders, Depression, Anxiety, Stress

Posted Date: December 7th, 2020

DOI: https://doi.org/10.21203/rs.3.rs-63503/v1

License: (c) (1) This work is licensed under a Creative Commons Attribution 4.0 International License. Read Full License 


\section{Abstract}

Background: The role of diet in developing psychological disorders has been considered by researchers in recent years.

Objective: To examine the association between major dietary patterns and severe mental disorders in a large sample of adults living in Yazd city, central Iran.

Methods: This cross-sectional study used the baseline data of a population-based cohort study (Yazd Health study: YaHS). Dietary intakes were assessed by a multiple-choice semi-quantitative food frequency questionnaire (FFQ) in the Yazd Nutrition survey (TAMYZ). Psychological assessments were also done by using depression, anxiety, and stress scale-21 (DASS-21) questionnaire. Major dietary patterns were identified using principal component analysis (PCA). Multivariate linear and logistic regression analyses were used to evaluate the relationship between dietary patterns' scores and mental disorders.

Results: A total of 7574 participants were included in the current analysis. Four major dietary patterns were identified: "Sugar and Fats", "Red meat and Fish", "Fruits" and "Vegetables". After adjustment for all confounding variables, participants in the fifth quintile of "Fruits" dietary pattern which was correlated with dried fruits, canned fruits, fruit juice, olive, hydrogenated fats and fruits had a lower odds of severe depression (OR: 0.61, 95\% Cl: 0.450.81 , $\mathrm{P}$ trend=0.008), anxiety (OR: $0.64,95 \% \mathrm{Cl}: 0.50-0.80, \mathrm{P}$ trend=0.001), and stress, (OR: $0.45,95 \% \mathrm{Cl}: 0.30-0.68, \mathrm{P}$ trend=0.001).

Conclusions: The intake of a dietary pattern high in dried fruits, canned fruits, fruit juice, olive, hydrogenated fats and fruits might be inversely associated with depression, anxiety and stress. Future prospective studies are needed to warrant this finding.

\section{Introduction}

A large number of people are affected by common mental disorders including depression and anxiety around the world [1]; as between 1990 and 2013, the number of individuals suffering from depression and/or anxiety augmented by almost 50\%, from 416 million to 615 million [2]. Furthermore, depression, anxiety and psychological distress are regarded as the important causes for disability, high economic burden and early mortality [3]. It has been shown that depression and anxiety are prevalent among $21.0 \%$ and $20.8 \%$ of Iranians, respectively [4].

It is proposed that lifestyle changes might explain the increased prevalence of mental disorders over recent decades [5]. Dietary intakes also play a role [6]. The majority of previous investigations regarding the association between diet and mental disorders have focused on individual nutrients, specific foods, and food groups [7]. For example, dietary intakes of iron [8], selenium and zinc [9], vitamin B6 [10], folate, vitamin B12 [9], omega-3 fatty acids [11], choline [12], fish [13] and vegetables [14] have been shown to be associated with depression, anxiety, and stress. However, foods are not usually consumed individually, so their combined effect on mental disorders may differ from their isolated effects [15].

Empirically derived dietary patterns have lately appeared in nutritional epidemiology to examine associations between diet and chronic diseases [16]. In this approach, multiple nutrients or foods are combined using statistical methods to derive a single variable, namely dietary pattern [17]. It has been supposed that dietary patterns provide better and more general look into diet-disease relations [16] and may be more predictive of chronic disease risk than individual foods or nutrients [17].

Several studies have assessed the association between empirically derived dietary patterns and mental disorders. In a study on Australian adult women, the results show that a "traditional" dietary pattern (high intakes of fruit, vegetables, whole grains, meat and fish) has been protectively associated with depression [18]. Adherence to a "whole food" dietary pattern was linked with decreased risk, while a "processed food" dietary pattern increased risk of depression in British middle-aged women [19]. In the Norwegian population a western-type diet was associated with increased anxiety in women and men before final adjustment for energy intake; furthermore a traditional Norwegian dietary pattern was also linked with reduced depression in women and anxiety in men [20]. Similar findings have also been demonstrated in Chinese adolescents [21]. A strong positive association has been found between "Western" dietary pattern and anxiety and stress; also, there was an inverse association between Mediterranean-type dietary pattern and anxiety in Iranian population [22]. The majority of studies have tried to assess the relationship between dietary patterns and depression, this is while a few number of studies have focused on association between dietary patterns and anxiety [23].

The previous studies from Middle East were conducted in a limited number of participants and led to inconsistent results; furthermore the major dietary patterns might be different between societies with heterogeneity in food culture, like Iran [24, 25]. Therefore, the aim of the present study was to examine the association between major dietary patterns identified by principal components analysis and depression, anxiety and stress in a large sample of adults living in Yazd city, central Iran.

\section{Methods}

\section{Study design and population}

The present study was carried out on the recruitment phase data of a population-based cohort study titled: "Yazd Health Study (YaHS)", which has been the most comprehensive study on the health and diseases in Yazd Greter Area (www.yahs-ziba.com). The participants were aged 20-70 years. Detailed information of the study design, participants recruitment and data collection methods are explained previously [26]. In YaHS study, data on general characteristics, personal and dietary habits, physical activity, medical history, mental health status and social well-being of the participants plus blood 
pressure, and anthropometric measurements were collected from 10000 participants by trained interviewers. Dietary foods and supplements intake data were collected in the second phase in a study named as Yazd Nutrition Survey (YNS) which locally known as TAMYZ in Persian (TAghzieh-e-Mardome YaZd) by using a multiple-choice semi-quantitative food frequency questionnaire (FFQ) which was filled by trained interviewers. After merging data from YaHS and TAMYZ data, 9962 were left for further analysis. Participants with missing data $(n=1029)$, chronic diseases including heart disease and different cancers $(n=909)$ were removed. In addition, those with energy intake lower than 800 Kcal and higher than 7000 Kcal were considered as underand over-reporters, respectively and were removed from the study. In overall, 7574 participants were left to be entered to the current analysis. The methodology of the present study was approved by the ethics committee of Shahid Sadoughi University of Medical Sciences (approval code: IR.SSU.SPH.REC.1398.011) and written informed consents for entering the study and publication of study results were taken from all participants.

\section{Dietary assessment method}

The dietary assessment in TAMYZ was done by using a 178-item semi-quantitative multiple-choice FFQ which showed an acceptable validity and reliability [27]. For each food item, participants were asked to report the i) frequency of food consumption in the past year based on 10 multiple-choice frequency response categories varying from 'never or less than once a month' to '10 or more times per day', and ii) amount of food consumed each time (portion size). The portion size was determined using questions with five predefined answer categories which were different, according to each food item. Furthermore, participants were asked to complete a separate multiple-choice questionnaire about the frequency of the selected supplements (ie, vitamin D, calcium, iron, folic acid, fish oil (or omega-3) and multivitamin-mineral supplements). Food items were categorized into 40 food groups to be included in the dietary pattern analysis. Dietary food groups and their corresponding food items are provided in Supplementary Table 1.

\section{Assessment of the psychological profile}

The depression, anxiety, and stress Scale - 21 (DASS-21) questionnaire was used to assess depression, anxiety and stress. The questionnaire is composed of three 7-item subscales: depression, anxiety, and stress. Participants were asked to rate how much each item described their experience over the past week ranging from 0 (did not apply to me at all - never) to 3 (applied to me very much, or most of the time-almost always). Subscale scores were calculated by summing up the related items. Generally, higher scores indicate a greater level of psychological disorders. This questionnaire was validated by Sahebi et al. for the Iranian population. The details of the scoring method have already been described elsewhere [28]. For the current study participants were classified into one of the five primary classification based on their scores, which include the absence of disease, mild, moderate, severe and very severe. Finally, the individuals were classified into two main categories: Without psychological disorders (individuals who were classified as absence of disease, mild and moderate) and with severe psychological disorders (individuals who were classified as severe and very severe).

\section{Anthropometric measurements}

Anthropometric measurements including height, weight, waist circumference and hip circumference were performed three times (before starting the interview, again after completing one-third of the questionnaire and for a final time after having completed two-thirds of the questionnaire) by trained interviewers. Also, BMI was calculated as weight $(\mathrm{kg})$ divided by height squared $(\mathrm{m})$.

\section{Assessment of other variables}

Demographics including age, gender, marital status (single/married/divorced or widow), education (uneducated/middle school/high School/bachelor's degree/master's degree or higher), and job status (unemployed/government-employed/manual worker/self-employed), smoking status (never smoker/current smoker/ex-smoker), diabetes (yes/no), hypertension (yes/no), and home ownership status (yes/no) were collected through a selfadministered questionnaire. The short Version of International Physical Activity Questionnaire (IPAQ) was used to measure physical activity level and results were expressed as metabolic equivalent in minutes per week (MET-min/wk) [29].

\section{Statistical analysis}

Principal components analysis with orthogonal transformation was used to derive major dietary patterns on the basis of forty food groups. Eigenvalues $(>1)$, Scree plot and factor interpretability were considered to select the major dietary patterns [30]. Each food group received a factor loading associated with each dietary pattern. Factor loadings show the correlation coefficient between the food group and the dietary pattern. After that, the factor score for each dietary pattern was computed by summing up intakes of food groups weighted by their factor loadings. Participants received a factor score for each identified dietary pattern and were categorized based on quintiles of dietary patterns' scores.

Continuous and categorical variables were compared across quintiles of dietary patterns intake scores using analysis of variance (ANOVA) and chisquare tests, respectively. We compared age, sex and energy standardized dietary food groups and nutrients intakes across quintiles of dietary patterns' scores using analysis of covariance (ANCOVA) with Bonferroni correction. This method was also applied to compare depression, anxiety and stress scores across quintiles of derived dietary patterns in crude and two multi-variable adjusted models. Age, sex (male/female) and energy intake (kcal/day) were adjusted in the first model (model 1), and then BMI $\left(\mathrm{kg} / \mathrm{m}^{2}\right)$, physical activity (MET-min/week), marital status (single/married/widowed or divorced), smoking status (yes/no), job status (unemployed /government employed/manual worker/self-employed), education status (uneducated /middle school /high school or diploma /bachelor's degree /master's degree or higher), home ownership (yes/no), diabetes (yes/no) and hypertension (yes/no) were further adjusted in the second model (model 2). Furthermore, to determine the association between dietary patterns, and the likelihood of developing depression, anxiety and stress, the binary logistic regression was applied in crude and multi-variable adjusted models. All statistical analyses were conducted using the Statistical Package for Social Sciences (SPSS, version 15.0 for Windows, 2006, SPSS, Inc, Chicago, IL). P values less than 0.05 were regarded as statistically significant. 


\section{Results}

In total, 7574 participants (3763 males and 3811 females) were included in the current analysis. Four major dietary patterns were identified using principal components analysis, which were labeled as "sugar and fats", "red meat and fish", "fruits" and "vegetables". These four dietary patterns explained $18.63 \%$ of the total variation in dietary intakes in this population. The "Sugar and Fats" dietary pattern was characterized by high consumption of sweets and desserts, nuts, snack foods, broth, condiment, sugars and mayonnaise and explained $6.87 \%$ of the total variance. The "Red meat and Fish" dietary pattern was mainly loaded by processed meats, fish and organ meats and explained by $4.12 \%$ of the total variance. The "Fruits" dietary pattern was associated with higher intakes of dried fruits, canned fruits, fruit juice, olive, hydrogenated fats and fruits and explained $3.86 \%$ of the total variance. Tomatoes, green leafy vegetables, other vegetables, red meats and fruits were highly loaded in the "vegetables" dietary pattern which explained by $3.78 \%$ of the total variance. All food groups as well as their loading factors for each dietary pattern are shown in Table 1. The high positive loadings demonstrate strong positive relation between food groups and dietary patterns, whereas high negative loadings indicate strong negative association.

The general characteristics of the study participants across quintiles of dietary patterns' (DPs') scores are presented in Table 2. Participants in the fifth quintile of the "Sugar and Fats" pattern were more likely to be younger, employed, with higher physical activity, with low education and with lower waist and hip circumferences $(\mathrm{P}<0.05)$. Participants with highest "Red meat and Fish" dietary pattern score were younger, with higher physical activity and with lower waist circumference $(\mathrm{P}<0.05)$. Participants in the top quintile of "fruits" dietary pattern had a higher body mass index, waist and hip circumferences, lower physical activity, average education (high school diploma). The adherence to the "vegetables" diet was associated with average education (high school diploma). There was no significant difference in other quantitative and qualitative variables across quintiles of "vegetables" dietary pattern (Table 2).

Age-, sex- and energy-adjusted intakes of selected food groups and nutrients across quintile categories of major DPs' scores are provided in Table 3. Compared with those in the lowest quintile of the "Sugar and Fats" dietary pattern, participants in the top quintile had significantly higher intakes of energy, total carbohydrate, mono-unsaturated, poly-unsaturated and total fat, sugar, vitamin $E$ (alpha-tocopherol), and nuts intake $(P<0.05)$; however, they had lower intakes of whole and refined grains, low and high fat dairy products, processed and red meats, legumes, fruits, vegetables, total protein, saturated fat, vitamin $\mathrm{C}$, thiamine, riboflavin, vitamin B6, B12, folic Acid, magnesium, calcium and iron $(P<0.05)$. Participants in the highest quintile of the "Red meat and Fish" dietary pattern had significantly higher intakes of refined grains, high fat dairy products, processed meats, vegetables, legumes, energy, saturated, mono-unsaturated and total fat, total protein, thiamine, riboflavin, vitamin B6, B12, folic Acid, magnesium and calcium ( $P<0.05$ ). Individuals in higher quintiles of the "Fruits" dietary pattern consumed more refined grains, low fat dairy products, fruits, vegetables, energy, total protein, vitamins C, E (alpha-tocopherol), thiamine, riboflavin, B6, B12, folic Acid, magnesium, calcium and iron $(P<0.05)$. Furthermore, subjects in the highest quintiles consumed less amounts of high fat dairy products, legumes, nuts, red meat, total carbohydrate, saturated, mono-unsaturated and total fat $(\mathrm{P}<$ 0.05). The "vegetables" dietary pattern was positively associated with high fat dairy products, legumes, fruits, vegetables, red meat, energy, total protein, vitamin C, E (alpha-tocopherol), thiamine, riboflavin, vitamin B6, B12, folic Acid, magnesium, calcium, and iron intake and inversely associated with whole and refined grains, low fat dairy products, nuts, processed meats, saturated, poly-unsaturated and total fat and total carbohydrate intake $(P<0.05)$.

Table 4 displays crude and multivariable-adjusted mean scores for depression, anxiety and stress across quintiles of dietary pattern scores. The analyses revealed that participants in the top quintile of the "Sugar and Fats" dietary pattern hade lower anxiety score than those in the bottom quintile in crude model (crude: $2.81 \pm 0.09$ vs. $3.33 \pm 0.09, P<0.001$ ). The association remained significant even after adjustment for all possible confounds in model 2 ( $2.94 \pm 0.11$ vs. $3.05 \pm 0.10, P=0.01)$. We found no significant difference in depression and stress scores across quintiles of "Sugar and Fats" dietary pattern scores either in crude or multi-variable adjusted models. Although significant differences were observed in anxiety and stress score between participants in different quintiles of "Red meat and Fish" dietary pattern in the crude model $(\mathrm{P}<0.05)$, the significant differences were vanished after adjustment for all possible confounders $(P>0.05)$. Participants who highly adhered to the 'Fruits' dietary pattern had lower depression and anxiety scores compared to those with lower adherence to this DP $(P<0.001)$ and the association remained significant after further adjustments for potential confounders in models 1 and $2(\mathrm{P} \leq 0.05)$; There was no significant association between 'Fruits' dietary pattern and stress scores either in crude or multivariable adjusted models $(P>0.05)$. Participants in top quintile of "vegetables" dietary had a significantly higher depression, anxiety, and psychological distress scores either in crude or in multi-variable adjusted models $(P<0.05)$.

Crude and multivariable-adjusted odds ratios (ORs) and 95\% Cls for severe depression, anxiety and psychological distress across quintiles of DPs' score are presented in Table 5. The analysis revealed that compared with the first quintile, participants in the fifth quintile of "Fruits" dietary pattern had lower odds of severe depression (OR: $0.61,95 \% \mathrm{Cl}: 0.45-0.81, \mathrm{P}$ trend $=0.008)$, anxiety (OR: $0.64,95 \% \mathrm{Cl}: 0.50-0.80, \mathrm{P}$ trend $=0.001)$, and stress, $(\mathrm{OR}$ : $0.45,95 \%$ Cl: $0.30-0.68, \mathrm{P}$ trend $=0.001)$. This association remained significant for depression (OR: $0.63,95 \%$ Cl: $0.46-0.87)$, anxiety (OR: $0.64,95 \%$ Cl: $0.48-0.84$ ), and stress (OR: $0.46,95 \% \mathrm{Cl}: 0.29-0.74)$ even after adjustment for all potential confounders in model; however, the linear trend for the association between this dietary pattern and odds of depression $(P=0.057)$ and psychological distress $(P=0.081)$ became marginally significant in this model. The other dietary patterns were associated with likelihood for developing depression, anxiety and psychological distress neither in crude nor in multi-variable adjusted models.

\section{Discussion}

In this cross-sectional study, we identified four dietary patterns including "Sugar and Fats", "Red meat and Fish", "Fruits" and "Vegetables". We found an inverse association between the "Fruits" pattern and likelihood of severe depression, anxiety and psychological distress, but none of the other dietary patterns were associated with severe mental disorders. 
Psychological disorders impose great socio-economic expenses on individuals and societies and can increase the mortality rate [31]. So, effective strategies to prevent these conditions are necessary [32]. Our results suggested that fruit dietary pattern, loaded with high intake of dried fruits, canned fruits, fruit juice, olive and olive oil, hydrogenated fats and fruits is inversely associated with severe depression, anxiety and stress. These findings are closely concordant with other reports, in which fruits consumption was shown to be associated with lower odds of psychological disorders [33-35], but several studies have reached no significant association between fruits consumption and psychological disorders [36, 37]. A meta-analysis study on fruit and vegetable consumption and risk of depression was shown that every $100-\mathrm{g}$ increased intake of fruit was associated with a $3 \%$ reduced risk in depression in cohort studies [38]. There are several underlying mechanisms that could explain the association between fruit dietary pattern and mental health. There are a large number of bioactive compounds such as vitamins, minerals, fiber, antioxidants, flavonoids, and phytochemicals in fruits that may be efficacious in prevention of mental disorders [39]. The brain is vulnerable to oxidative stress. Oxidative stress, neuro-inflammation and modifications of synaptic molecules are important risk factors of psychological disorders, including depression and anxiety [40]. Antioxidants in fruits such as vitamin C, vitamin E, phenolic compounds and carotenoids can protect brain against oxidative, inflammatory, neuronal and stress-induced damages [41, 42]. Moreover, dietary antioxidants have protective effects against mitochondrial damages, which are common among individuals with psychological disorders [43]. On the other hand, deficiency of some nutrients such as folate might contribute to mental disorders. Folate, as a substance found in fruits can enhance methylation processes and the regulation of neurotransmitters, such as serotonin, to reduce risk of depression [35]. In a meta-analysis study folate has been inversely associated with depression [44]. Olive and olive oil, one of the components of the fruits dietary pattern in our study, may also have inverse association with psychological disorders. Olive oil produces psychoactive lipid oleamide, which can induce sleep and modulates serotonin receptor-mediated signaling [45]. According to logistic regression, we found that the "Vegetables" dietary pattern, loaded by tomatoes, green leafy vegetables, other vegetables, red meats and fruits had no significant association with depression, anxiety and stress categories. Previous studies led to inconsistent findings about the relationship between vegetables consumption and psychological health. In line with our study, Pengpid et al found that vegetable consumption did not significantly decrease the risk of major depression and generalized anxiety disorder [37]. Also, these findings were consistent with a study in Iranian which stated that vegetable consumption was not associated with anxiety and stress [22]. On the other hand, several studies have shown that vegetable consumption has a protective effect against mental disorders [19, 23]. A meta-analysis study on fruit and vegetable consumption and risk of depression was shown that with regard to vegetable consumption, every 100-g increase in intake was associated with $5 \%$ reduced odds of depression in cross-sectional studies and $3 \%$ reduced risk in cohort studies [38]. One of the justifying reasons that can explain this relation is that meats also loaded in vegetable pattern, and this might prevent finding the inverse association.

We found no significant associations between "Red meat and Fish" and "Sugar and Fats" dietary patterns and severe mental disorders. These patterns loaded with high intake of sweets and desserts, nuts, snack foods, broth, condiment, sugars and mayonnaise, processed meats, fish and organ meats. In contrast with our results a study of Iranian adults, a western dietary pattern characterized by high intakes of sweets and desserts, snacks, chocolate, high-fat dairy products, carbonated drinks, processed meats, mayonnaise and pickles was associated with increased odds of anxiety in normal-weight participants and depression in men [46]. Jaka et al concluded that the western dietary pattern characterized by high consumption of meat and liver, processed meats, pizza, salty snacks, chocolates, sugar and sweets, soft drinks, margarine, mayonnaise and french fries was associated with increased odds of anxiety in Australian men and women [20]. In line with our results, Nasir et al found that unhealthy dietary pattern loaded heavily on high-energy drinks and beverages, fast foods, seasonings, sweets and desserts, snacks, solid fat, pickle, mayonnaise and high-fat dairy products did not significantly associate with depression, anxiety, and stress score [47]. It is worth mentioning that the food content of western-type or unhealthy dietary patterns in the different studies, as well as the interactions of various food items in the dietary patterns, might explain these inconsistencies. It should be also mentioned that both healthy and unhealthy food group were simultaneously loaded in "Red meat and Fish" and "Sugar and Fats" dietary patterns and this might explain the non-significant associations found in the present study.

The present study has several strengths. The previous investigations from Middle East were conducted in a limited number of participants while the current study was conducted in the large sample size including both sexes of Iranian adults. Moreover, we adjusted for a wide range of confounders that might affect psychological situations. In addition, the study participants were selected from general population and this will help the generalizability of our results. This is while the majority of previous investigations were conducted in a specific population, a specific age group, or a particular gender. After all, to the best of our knowledge, it is the first study that reports the relationship between major dietary patterns and severe psychological disorders in a Middle Eastern country; This is while other studies also included those with moderate disorders.

There are a number of limitations to our study that should be interpreted with caution. First, because of the cross-sectional design, causality cannot be inferred from the current findings; therefore, prospective observational studies like cohort or nested case control studies are highly necessitated to confirm our results. Although we used a validated FFQ for the assessment of dietary intakes, some degree of measurement error and misclassification might be distorted the results [48]. In spite of controlling for a wide range of confounding variables in our analyses, it is not possible to exclude the effects of residual confounding from unknown or unmeasured factors. The subjective or arbitrary decisions have been made when determining the number of factors to extract and choosing the method of rotation and labeling the main factors.

\section{Conclusions}

In conclusion, this cross-sectional study demonstrated that adherence to a dietary pattern highly associated with greater intakes of dried fruits, canned fruits, fruit juice, olive and olive oil, hydrogenated fats and fruits can be linked with decreased odds of severe depression, anxiety and stress in large sample of adults living in Yazd city, central Iran. Further prospective investigations are required to confirm our findings. 


\section{Abbreviations}

\section{DASS-21}

depression, anxiety, and stress scale-21

\section{FFQ}

food frequency questionnaire

IPAQ

International Physical Activity Questionnaire

PCA

principal component analysis

\section{TAMYZ}

TAghzieh-e-Mardome YaZd

YaHS

Yazd Health Suurvey

YNS

Yazd Nutrition Survey

\section{Declarations}

\section{Ethics approval and consent to participate}

The methodology of the present study was approved by the ethics committee of Shahid Sadoughi University of Medical Sciences (approval code: IR.SSU.SPH.REC.1398.011) and written informed consents for entering the study and publication of study results were taken from all participants.

\section{Consent for publication}

No individual detail is presented in this manuscript; therefore, it is not applicable.

\section{Availability of data and material}

The data of the present study will be available for the corresponding author. The data used for the current study are already published in individual papers. The data can be obtained from the corresponding author.

\section{Acknowledgements}

The authors would like to thank all participants who attended the study. We also thank the YaHS-TAMYZ cohort study investigators for sharing the data.

\section{Funding Source}

The current study was derived from a dissertation for Master's degree in Public Health Nutrition which was funded by Shahid Sadoughi University of Medical Sciences for planning and conducting the analyses.

\section{Authors' contribution}

ASA, SSR conceived the study. ASA and SSR conducted the statistical analyses. ASA approved the methodology. SSR wrote the first draft of the manuscript. MM is the chief investigator and founder of YaHS. All authors contributed to the conception, design and drafting of the manuscript.

\section{Competing interest}

The authors declare that they have no competing interest.

\section{References}

1. Salehi-Abargouei A, Esmaillzadeh A, Azadbakht L, Keshteli AH, Afshar H, Feizi A, et al. Do patterns of nutrient intake predict self-reported anxiety, depression and psychological distress in adults? SEPAHAN study. Clin Nutr. 2019;38:940-7. 
2. Organization WH. Investing in treatment for depression and anxiety leads to fourfold return. Retrieved from October. 2016;22:2018.

3. Shrivastava S, Shrivastava P, Ramasamy J. Addressing the public health concern of depression and anxiety disorders: Financial perspective. Annals of Tropical Medicine Public Health. 2017;10:309-10.

4. Noorbala AA, Yazdi SB, Yasamy M, Mohammad K. Mental health survey of the adult population in Iran. The British Journal of Psychiatry. 2004;184:70-3.

5. Sarris J, O’Neil A, Coulson CE, Schweitzer I, Berk M. Lifestyle medicine for depression. BMC Psychiatry. 2014;14:107.

6. Lai JS, Hiles S, Bisquera A, Hure AJ, McEvoy M, Attia J. A systematic review and meta-analysis of dietary patterns and depression in communitydwelling adults. Am J Clin Nutr. 2013;99:181-97.

7. Murakami K, Sasaki S. Dietary intake and depressive symptoms: a systematic review of observational studies. Molecular nutrition food research. 2010;54:471-88.

8. Zhang L, Kleiman-Weiner M, Luo R, Shi Y, Martorell R, Medina A, et al. Multiple micronutrient supplementation reduces anemia and anxiety in rural China's elementary school children. J Nutr. 2013;143:640-7.

9. Popa T, Ladea M. Nutrition and depression at the forefront of progress. Journal of medicine life. 2012;5:414.

10. De Souza MC, Walker AF, Robinson PA, Bolland K. A synergistic effect of a daily supplement for 1 month of 200 mg magnesium plus 50 mg vitamin B6 for the relief of anxiety-related premenstrual symptoms: a randomized, double-blind, crossover study. J Womens Health Gend Based Med. 2000;9:131-9.

11. Liu JJ, Galfalvy HC, Cooper TB, Oquendo MA, Grunebaum MF, Mann JJ, et al. Omega-3 polyunsaturated fatty acid status in major depression with comorbid anxiety disorders. J Clin Psychiatry. 2013;74:732.

12. Bjelland I, Tell GS, Vollset SE, Konstantinova S, Ueland PM. Choline in anxiety and depression: the Hordaland Health Study. The American Journal of Clinical Nutrition. 2009;90:1056-60.

13. Tanskanen A, Hibbeln JR, Tuomilehto J, Uutela A, Haukkala A, Viinamäki H, et al. Fish consumption and depressive symptoms in the general population in Finland. Psychiatric Services. 2001;52:529-31.

14. Mikolajczyk RT, El Ansari W, Maxwell AE. Food consumption frequency and perceived stress and depressive symptoms among students in three European countries. Nutrition journal. 2009;8:31.

15. Liu L, Nettleton JA, Bertoni AG, Bluemke DA, Lima JA, Szklo M. Dietary pattern, the metabolic syndrome, and left ventricular mass and systolic function: the Multi-Ethnic Study of Atherosclerosis. Am J Clin Nutr. 2009;90:362-8.

16. Hu FB. Dietary pattern analysis: a new direction in nutritional epidemiology. Curr Opin Lipidol. 2002;13:3-9.

17. Newby P, Tucker KL. Empirically derived eating patterns using factor or cluster analysis: a review. Nutrition reviews. 2004;62:177-203.

18. Jacka FN, Pasco JA, Mykletun A, Williams LJ, Hodge AM, O'Reilly SL, et al. Association of Western and traditional diets with depression and anxiety in women. Am J Psychiatry. 2010;167:305-11.

19. Akbaraly TN, Brunner EJ, Ferrie JE, Marmot MG, Kivimaki M, Singh-Manoux A. Dietary pattern and depressive symptoms in middle age. The British Journal of Psychiatry. 2009;195:408-13.

20. Jacka FN, Mykletun A, Berk M, Bjelland I, Tell GS. The association between habitual diet quality and the common mental disorders in communitydwelling adults: the Hordaland Health study. Psychosom Med. 2011;73:483-90.

21. Weng T-T, Hao J-H, Qian Q-W, Cao H, Fu J-L, Sun Y, et al. Is there any relationship between dietary patterns and depression and anxiety in Chinese adolescents? Public Health Nutr. 2012;15:673-82.

22. Kamali M, Dastsouz F, Sadeghi F, Amanat S, Akhlaghi M. Associations between Western and Mediterranean-type dietary patterns and anxiety and stress. Acta Aliment. 2016;45:398-405.

23. McMartin SE, Jacka FN, Colman I. The association between fruit and vegetable consumption and mental health disorders: evidence from five waves of a national survey of Canadians. Preventive medicine. 2013;56:225-30.

24. Djazayery A, Mehrabi Y, Azizi F. Change in food patterns of Tehrani adults and its association with changes in their body weight and body mass index in District 13 of Tehran: Tehran Lipid and Glucose Study. Iranian Journal of Nutrition Sciences Food Technology. 2008;2:67-80.

25. Willett W. Nutritional epidemiology: Oxford university press; 2012.

26. Mirzaei M, Salehi-Abargouei A, Mirzaei M, Mohsenpour MA. Cohort Profile: The Yazd Health Study (YaHS): a population-based study of adults aged 20-70 years (study design and baseline population data). International Journal of Epidemiology. 2017;47:697-8 h.

27. Zimorovat A, Moghtaderi F, Amiri M, Raeisi-Dehkordi H, Mohyadini M, Mohammadi M, et al. Validity and reproducibility of a semi-quantitative multiple-choice food frequency questionnaire in adults living in central Iran. In Review; 2020.

28. Sahebi A, Asghari MJ, Salari R. Validation of depression anxiety and stress scale (DASS-21) for an Iranian population. 2005.

29. Moghaddam MB, Aghdam FB, Jafarabadi MA, Allahverdipour H, Nikookheslat SD, Safarpour S. The Iranian Version of International Physical Activity Questionnaire (IPAQ) in Iran: content and construct validity, factor structure, internal consistency and stability. World applied sciences journal. 2012;18:1073-80.

30. Kim J-O, Mueller CW. Factor analysis: Statistical methods and practical issues: sage; 1978.

31. Mathers C. The global burden of disease: 2004 update: World Health Organization; 2008.

Page $7 / 18$ 
32. Saxena S, Jané-Llopis E, Hosman C. Prevention of mental and behavioural disorders: implications for policy and practice. World Psychiatry. 2006;5:5.

33. Mihrshahi S, Dobson A, Mishra G. Fruit and vegetable consumption and prevalence and incidence of depressive symptoms in mid-age women: results from the Australian longitudinal study on women's health. Eur J Clin Nutr. 2015;69:585-91.

34. Saghafian F, Malmir H, Saneei P, Keshteli AH, Hosseinzadeh-Attar MJ, Afshar H, et al. Consumption of fruit and vegetables in relation with psychological disorders in Iranian adults. Eur J Nutr. 2018;57:2295-306.

35. Richard A, Rohrmann S, Vandeleur CL, Mohler-Kuo M, Eichholzer M. Associations between fruit and vegetable consumption and psychological distress: results from a population-based study. BMC Psychiatry. 2015;15:213.

36. Bhattacharyya M, Marston L, Walters K, D'Costa G, King M, Nazareth I. Psychological distress, gender and dietary factors in South Asians: a crosssectional survey. Public Health Nutr. 2014;17:1538-46.

37. Pengpid S, Peltzer K. Association Between Fruit/Vegetable Consumption and Mental-Health-Related Quality of Life, Major Depression, and Generalized Anxiety Disorder: A Longitudinal Study in Thailand. Iran J Psychiatry Behav Sci. 2019;13:e88246.

38. Saghafian F, Malmir H, Saneei P, Milajerdi A, Larijani B, Esmaillzadeh A. Fruit and vegetable consumption and risk of depression: accumulative evidence from an updated systematic review and meta-analysis of epidemiological studies. Br J Nutr. 2018;119:1087-101.

39. Alexopoulos GS. Depression in the elderly. The lancet. 2005;365:1961-70.

40. Payne ME, Steck SE, George RR, Steffens DC. Fruit, vegetable, and antioxidant intakes are lower in older adults with depression. Journal of the Academy of Nutrition Dietetics. 2012;112:2022-7.

41. Rink SM, Mendola P, Mumford SL, Poudrier JK, Browne RW, Wactawski-Wende J, et al. Self-report of fruit and vegetable intake that meets the 5 a day recommendation is associated with reduced levels of oxidative stress biomarkers and increased levels of antioxidant defense in premenopausal women. Journal of the Academy of Nutrition Dietetics. 2013;113:776-85.

42. Leonard B, Maes M. Mechanistic explanations how cell-mediated immune activation, inflammation and oxidative and nitrosative stress pathways and their sequels and concomitants play a role in the pathophysiology of unipolar depression. Neuroscience Biobehavioral Reviews. 2012;36:76485.

43. Maciejczyk M, Mikoluc B, Pietrucha B, Heropolitanska-Pliszka E, Pac M, Motkowski R, et al. Oxidative stress, mitochondrial abnormalities and antioxidant defense in Ataxia-telangiectasia, Bloom syndrome and Nijmegen breakage syndrome. Redox Biology. 2017;11:375-83.

44. Gilbody S, Lightfoot T, Sheldon T. Is low folate a risk factor for depression? A meta-analysis and exploration of heterogeneity. Journal of Epidemiology Community Health. 2007;61:631-7.

45. Puri BK, Richardson AJ. The effects of olive oil on $\omega 3$ fatty acids and mood disorders. Arch Gen Psychiatry. 2000;57:715-.

46. Hosseinzadeh M, Vafa M, Esmaillzadeh A, Feizi A, Majdzadeh R, Afshar H, et al. Empirically derived dietary patterns in relation to psychological disorders. Public Health Nutr. 2016;19:204-17.

47. Nasir Y, Rahimi M-H, Molahosseini M, Yekaninejad S, Maghbooli Z, Mirzaei K. The association of major dietary patterns with depression, anxiety and stress in apparently healthy adults. Journal of Nutritional Sciences and Dietetics. 2016.

48. Keshteli AH, Esmaillzadeh A, Rajaie S, Askari G, Feinle-Bisset C, Adibi P. A dish-based semi-quantitative food frequency questionnaire for assessment of dietary intakes in epidemiologic studies in Iran: design and development. International journal of preventive medicine. $2014 ; 5: 29$.

\section{Tables}


Table 1

Loading factor for foods and foods groups based on major dietary patterns derived from principle component analysis ${ }^{1}$

\begin{tabular}{|c|c|c|c|c|}
\hline & Factor 1 & Factor 2 & Factor 3 & Factor 4 \\
\hline Sweets and desserts & 0.672 & - & - & - \\
\hline Nuts & 0.604 & - & - & - \\
\hline Soft drink & 0.585 & - & - & - \\
\hline Snacks & 0.532 & - & - & - \\
\hline Broth & 0.531 & - & - & - \\
\hline Condiment & 0.512 & - & - & - \\
\hline Sugars & 0.489 & - & - & - \\
\hline Mayonnaise & 0.444 & - & - & - \\
\hline Processed meats & - & 0.579 & - & - \\
\hline Fish & - & 0.520 & - & - \\
\hline Organ meats & - & 0.505 & - & - \\
\hline Yoghurt drink & - & - & - & - \\
\hline Dried fruits & - & - & 0.604 & - \\
\hline Canned fruits & - & - & 0.580 & - \\
\hline Fruit juice & - & - & 0.491 & - \\
\hline Olive & - & - & 0.376 & - \\
\hline Tomatoes & - & - & - & 0.648 \\
\hline Green leafy vegetables & - & - & - & 0.486 \\
\hline Other vegetables & - & - & - & 0.456 \\
\hline Fruits & - & - & 0.30 & 0.364 \\
\hline Potatoes & - & - & - & - \\
\hline French fries & - & - & - & - \\
\hline Red meats & - & - & - & 0.425 \\
\hline Refines grain & - & - & - & - \\
\hline Vegetables oil & - & - & - & - \\
\hline Low fat dairy products & - & - & - & - \\
\hline Salt & - & - & - & - \\
\hline Eggs & - & - & - & - \\
\hline Cruciferous vegetables & - & - & - & - \\
\hline Poultry & - & - & - & - \\
\hline Butter & - & - & - & - \\
\hline Margarine & - & - & - & - \\
\hline Pickles & - & - & - & - \\
\hline Tea & - & - & - & - \\
\hline Legumes & - & - & - & - \\
\hline Coffee & - & - & - & - \\
\hline Hydrogenated fats & - & - & 0.314 & - \\
\hline
\end{tabular}

${ }^{1}$ Loading factors lower than 0.3 are not shown for better interpretation of major dietary patterns. 


\begin{tabular}{|lllll|}
\hline & Factor $\mathbf{1}$ & Factor 2 & Factor 3 & Factor 4 \\
\hline High fat dairy products & - & - & - & - \\
\hline Whole grain & - & - & - & - \\
\hline Yellow vegetables & - & - & - & - \\
\hline Total variation explained & 6.87 & 4.12 & 3.86 & 3.78 \\
\hline${ }^{1}$ Loading factors lower than 0.3 are not shown for better interpretation of major dietary patterns. \\
\hline
\end{tabular}

Page 10/18 
Table 2

General characteristics of study participants according to quintiles of major dietary patterns' score

\begin{tabular}{|c|c|c|c|c|c|c|c|c|c|c|c|c|}
\hline & \multicolumn{3}{|l|}{ Factor 1} & \multicolumn{3}{|l|}{ Factor 2} & \multicolumn{3}{|l|}{ Factor 3} & \multicolumn{3}{|l|}{ Factor 4} \\
\hline & Q1 & Q5 & $\begin{array}{l}\text { P- } \\
\text { Value }\end{array}$ & Q1 & Q5 & $\begin{array}{l}\text { P- } \\
\text { Value }\end{array}$ & Q1 & Q5 & $\begin{array}{l}\text { P- } \\
\text { Value }\end{array}$ & Q1 & Q5 & $\begin{array}{l}\text { P- } \\
\text { Value }\end{array}$ \\
\hline Weight (kg) & $\begin{array}{l}72.51 \pm \\
14.17\end{array}$ & $\begin{array}{l}73.40 \pm \\
15.03\end{array}$ & 0.39 & $\begin{array}{l}72.82 \pm \\
14.17\end{array}$ & $\begin{array}{l}72.93 \pm \\
14.79\end{array}$ & 0.61 & $\begin{array}{l}72.62 \pm \\
14.55\end{array}$ & $\begin{array}{l}72.78 \pm \\
14.89\end{array}$ & 0.95 & $\begin{array}{l}72.01 \\
\pm 14.57\end{array}$ & $\begin{array}{l}73.44 \\
\pm 14.47\end{array}$ & 0.11 \\
\hline $\begin{array}{l}\text { Body mass index } \\
(\mathrm{kg} / \mathrm{m} 2)\end{array}$ & $\begin{array}{l}27.16 \pm \\
5.11\end{array}$ & $\begin{array}{l}27.16 \pm \\
5.27\end{array}$ & 0.14 & $\begin{array}{l}27.27 \pm \\
5.21\end{array}$ & $\begin{array}{l}26.95 \pm \\
5.12\end{array}$ & 0.15 & $\begin{array}{l}26.77 \pm \\
5.15\end{array}$ & $\begin{array}{l}26.95 \pm \\
5.25\end{array}$ & 0.04 & $\begin{array}{l}26.85 \\
\pm 5.14\end{array}$ & $\begin{array}{l}27.19 \\
\pm 5.02\end{array}$ & 0.34 \\
\hline $\begin{array}{l}\text { Waist } \\
\text { circumference } \\
(\mathrm{cm})\end{array}$ & $\begin{array}{l}94.66 \pm \\
12.97\end{array}$ & $\begin{array}{l}94.39 \pm \\
13.04\end{array}$ & 0.00 & $\begin{array}{l}94.55 \pm \\
12.82\end{array}$ & $\begin{array}{l}92.78 \pm \\
13.43\end{array}$ & 0.00 & $\begin{array}{l}92.97 \pm \\
13.04\end{array}$ & $\begin{array}{l}92.99 \pm \\
13.13\end{array}$ & 0.01 & $\begin{array}{l}93.23 \\
\pm 13.26\end{array}$ & $\begin{array}{l}94.00 \\
\pm 13.34\end{array}$ & 0.42 \\
\hline $\begin{array}{l}\text { Hip circumference } \\
(\mathrm{cm})\end{array}$ & $\begin{array}{l}103.28 \\
\pm 10.55\end{array}$ & $\begin{array}{l}100.88 \\
\pm 12.07\end{array}$ & 0.00 & $\begin{array}{l}102.10 \\
\pm 11.07\end{array}$ & $\begin{array}{l}101.22 \\
\pm 11.82\end{array}$ & 0.26 & $\begin{array}{l}100.97 \\
\pm 11.77\end{array}$ & $\begin{array}{l}101.59 \\
\pm 11.34\end{array}$ & 0.02 & $\begin{array}{l}101.40 \\
\pm 11.62\end{array}$ & $\begin{array}{l}102.42 \\
\pm 11.35\end{array}$ & 0.06 \\
\hline $\begin{array}{l}\text { Physical activity } \\
\text { (MET-min/week) }\end{array}$ & $\begin{array}{l}831.22 \\
\pm 866.15\end{array}$ & $\begin{array}{l}911.47 \\
\pm 912.93\end{array}$ & 0.00 & $\begin{array}{l}840.88 \\
\pm \\
880.24\end{array}$ & $\begin{array}{l}968.66 \\
\pm 936.27\end{array}$ & 0.00 & $\begin{array}{l}981.80 \\
\pm \\
949.77\end{array}$ & $\begin{array}{l}909.97 \\
\pm \\
905.53\end{array}$ & 0.00 & $\begin{array}{l}884.12 \\
\pm \\
921.41\end{array}$ & $\begin{array}{l}931.80 \\
\pm \\
926.61\end{array}$ & 0.55 \\
\hline \multicolumn{13}{|l|}{ Age group (\%) } \\
\hline $20-29$ & 18.8 & 22.5 & \multirow[t]{5}{*}{0.00} & 19.4 & 23.4 & \multirow[t]{5}{*}{0.01} & 23.1 & 21.8 & \multirow[t]{5}{*}{0.07} & 21.1 & 21.3 & \multirow[t]{5}{*}{0.56} \\
\hline $30-39$ & 19.5 & 23.5 & & 21.0 & 23.1 & & 21.2 & 23.7 & & 22.0 & 21.7 & \\
\hline $40-49$ & 21.6 & 21.6 & & 22.0 & 21.6 & & 21.5 & 21.9 & & 21.6 & 21.3 & \\
\hline $50-59$ & 20.9 & 17.3 & & 19.5 & 18.0 & & 19.7 & 18.2 & & 18.3 & 20.6 & \\
\hline $60-69$ & 19.2 & 15.1 & & 18.2 & 13.9 & & 14.5 & 14.4 & & 17.1 & 15.0 & \\
\hline Sex (female) (\%) & 52.2 & 49.6 & 0.40 & 51.9 & 48.9 & 0.39 & 47.8 & 49.5 & 0.19 & 49.9 & 49.8 & 0.62 \\
\hline \multicolumn{13}{|l|}{ Marital status (\%) } \\
\hline Single & 10.7 & 11.6 & \multirow[t]{3}{*}{0.36} & 11.2 & 11.8 & \multirow[t]{3}{*}{0.99} & 11.9 & 12.8 & \multirow[t]{3}{*}{0.62} & 12.4 & 11.9 & \multirow[t]{3}{*}{0.46} \\
\hline Married & 85.8 & 85.6 & & 85.5 & 84.9 & & 84.8 & 84.2 & & 85.2 & 84.9 & \\
\hline $\begin{array}{l}\text { Widowed or } \\
\text { divorced }\end{array}$ & 3.5 & 2.8 & & 3.2 & 3.3 & & 3.3 & 3.0 & & 2.4 & 3.3 & \\
\hline \multicolumn{13}{|l|}{ Education (\%) } \\
\hline Uneducated & 25.5 & 21.4 & \multirow[t]{5}{*}{0.00} & 23.4 & 23.6 & \multirow[t]{5}{*}{0.57} & 22.7 & 24.3 & \multirow[t]{5}{*}{0.00} & 25.2 & 23.3 & \multirow[t]{5}{*}{0.00} \\
\hline Middle school & 28.8 & 32.0 & & 30.6 & 26.8 & & 32.0 & 25.6 & & 28.8 & 27.5 & \\
\hline High School & 31.3 & 30.1 & & 30.5 & 30.5 & & 30.2 & 33.3 & & 30.4 & 32.3 & \\
\hline Bachelor's degree & 12.2 & 13.9 & & 12.8 & 12.8 & & 11.6 & 13.3 & & 13.9 & 12.7 & \\
\hline $\begin{array}{l}\text { Master's degree or } \\
\text { higher }\end{array}$ & 2.2 & 2.6 & & 2.6 & 2.6 & & 3.5 & 3.5 & & 1.7 & 4.3 & \\
\hline \multicolumn{13}{|l|}{ Job status (\%) } \\
\hline Unemployed & 18.4 & 22.6 & \multirow[t]{4}{*}{0.00} & 20.8 & 19.5 & \multirow[t]{4}{*}{0.27} & 20.4 & 18.5 & \multirow[t]{4}{*}{0.25} & 20.2 & 20.6 & \multirow[t]{4}{*}{0.62} \\
\hline $\begin{array}{l}\text { Government- } \\
\text { employed }\end{array}$ & 52.5 & 45.4 & & 49.4 & 46.1 & & 46.4 & 48.2 & & 48.6 & 46.4 & \\
\hline Manual worker & 3.3 & 4.1 & & 3.3 & 3.6 & & 3.4 & 3.5 & & 3.5 & 3.1 & \\
\hline Self-employed & 25.7 & 28.0 & & 26.6 & 30.8 & & 29.7 & 29.8 & & 27.6 & 29.8 & \\
\hline \multicolumn{13}{|l|}{$\begin{array}{l}\text { Smoking status } \\
(\%)\end{array}$} \\
\hline Never smoker & 88.1 & 88.0 & 0.89 & 87.0 & 89.3 & 0.10 & 86.0 & 89.0 & 0.14 & 87.4 & 86.8 & 0.78 \\
\hline
\end{tabular}




\begin{tabular}{|c|c|c|c|c|c|c|c|c|c|c|c|c|}
\hline & \multicolumn{3}{|c|}{ Factor 1} & \multicolumn{3}{|c|}{ Factor 2} & \multicolumn{3}{|c|}{ Factor 3} & \multicolumn{3}{|c|}{ Factor 4} \\
\hline & Q1 & Q5 & $\begin{array}{l}\text { P- } \\
\text { Value }\end{array}$ & Q1 & Q5 & $\begin{array}{l}\text { P- } \\
\text { Value }\end{array}$ & Q1 & Q5 & $\begin{array}{l}\text { P- } \\
\text { Value }\end{array}$ & Q1 & Q5 & $\begin{array}{l}\text { P- } \\
\text { Value }\end{array}$ \\
\hline Current smoker & 10.8 & 10.4 & & 10.9 & 9.6 & & 12.2 & 9.9 & & 11.0 & 11.4 & \\
\hline Ex-smoker & 1.1 & 1.6 & & 2.1 & 1.1 & & 1.9 & 1.1 & & 1.5 & 1.8 & \\
\hline \multicolumn{13}{|l|}{$\begin{array}{l}\text { Home ownership } \\
\text { (\%) }\end{array}$} \\
\hline Yes & 21.7 & 22.5 & \multirow[t]{2}{*}{0.12} & 22.2 & 21.3 & \multirow[t]{2}{*}{0.84} & 23.8 & 20.4 & \multirow[t]{2}{*}{0.02} & 23.4 & 20.5 & \multirow[t]{2}{*}{0.21} \\
\hline No & 78.3 & 77.5 & & 77.8 & 78.7 & & 76.2 & 79.6 & & 76.6 & 79.5 & \\
\hline
\end{tabular}


Table 3

Comparison of age, sex and energy adjusted dietary food groups and nutrients intake according to quintiles of dietary food patterns.

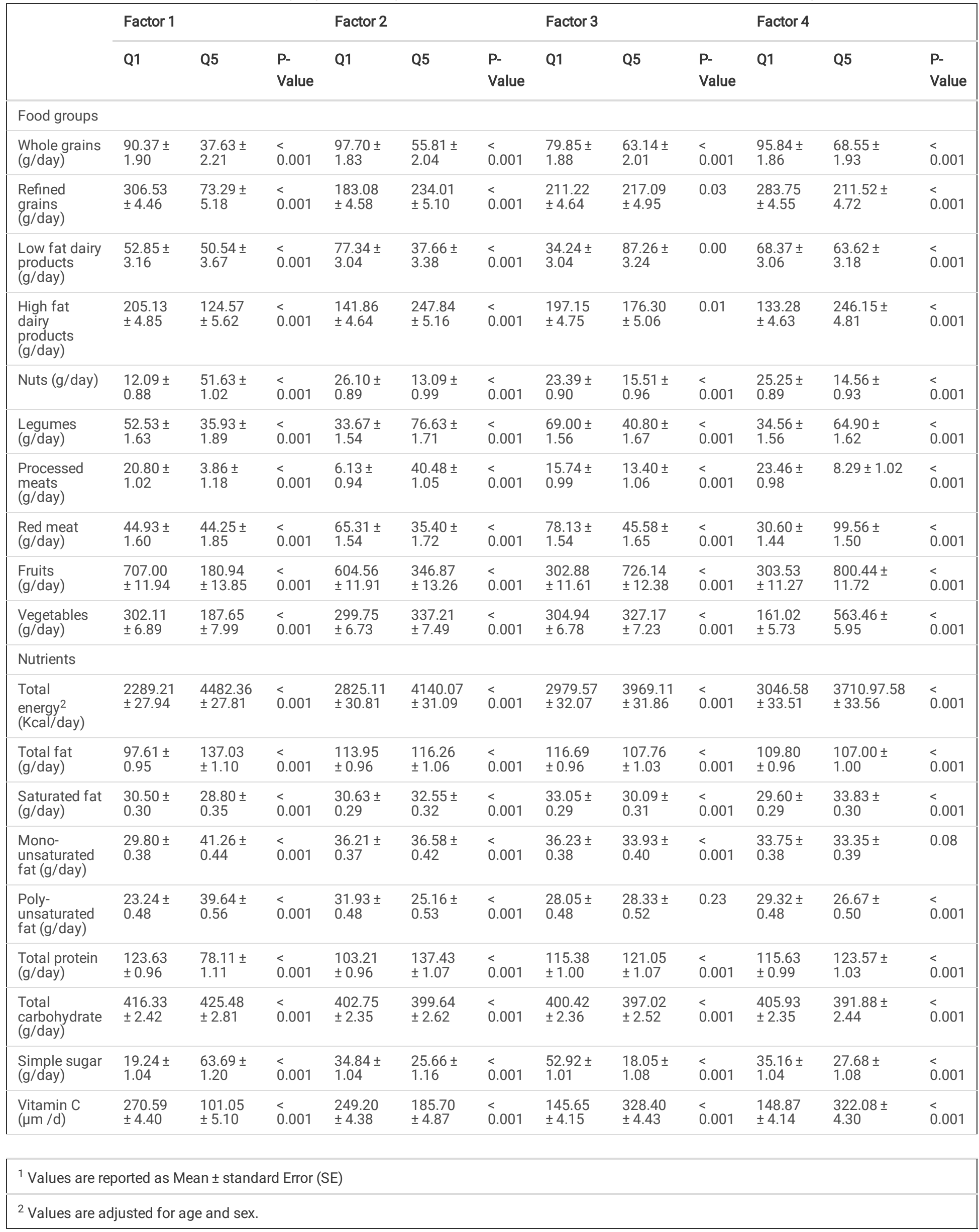




\begin{tabular}{|c|c|c|c|c|c|c|c|c|c|c|c|c|}
\hline & \multicolumn{3}{|l|}{ Factor 1} & \multicolumn{3}{|l|}{ Factor 2} & \multicolumn{3}{|l|}{ Factor 3} & \multicolumn{3}{|l|}{ Factor 4} \\
\hline & Q1 & Q5 & $\begin{array}{l}\text { P- } \\
\text { Value }\end{array}$ & Q1 & Q5 & $\begin{array}{l}\text { P- } \\
\text { Value }\end{array}$ & Q1 & Q5 & $\begin{array}{l}\text { P- } \\
\text { Value }\end{array}$ & Q1 & Q5 & $\begin{array}{l}\text { P- } \\
\text { Value }\end{array}$ \\
\hline $\begin{array}{l}\text { Vitamin } E \\
(\mu \mathrm{m} / \mathrm{d})\end{array}$ & $\begin{array}{l}21.98 \pm \\
0.82\end{array}$ & $\begin{array}{l}28.65 \pm \\
0.95\end{array}$ & $<.001$ & $\begin{array}{l}26.79 \pm \\
0.79\end{array}$ & $\begin{array}{l}19.68 \pm \\
0.88\end{array}$ & $<.001$ & $\begin{array}{l}19.50 \pm \\
0.79\end{array}$ & $\begin{array}{l}26.82 \pm \\
0.85\end{array}$ & $<.001$ & $\begin{array}{l}18.85 \pm \\
0.79\end{array}$ & $\begin{array}{l}29.48 \pm \\
0.82\end{array}$ & $\dot{0} .001$ \\
\hline $\begin{array}{l}\text { Thiamine } \\
(\mu \mathrm{m} / \mathrm{d})\end{array}$ & $\begin{array}{l}2.58 \pm \\
0.01\end{array}$ & $\begin{array}{l}1.45 \pm \\
0.01\end{array}$ & $<.001$ & $\begin{array}{l}2.12 \pm \\
0.01\end{array}$ & $\begin{array}{l}2.41 \pm \\
0.02\end{array}$ & $<.001$ & $\begin{array}{l}2.16 \pm \\
0.01\end{array}$ & $\begin{array}{l}2.29 \pm \\
0.01\end{array}$ & $<.001$ & $\begin{array}{l}2.21 \pm \\
0.01\end{array}$ & $2.54 \pm 0.01$ & $<.001$ \\
\hline $\begin{array}{l}\text { Riboflavin } \\
(\mu \mathrm{m} / \mathrm{d})\end{array}$ & $\begin{array}{l}2.48 \pm \\
0.01\end{array}$ & $\begin{array}{l}1.88 \pm \\
0.02\end{array}$ & $<.001$ & $\begin{array}{l}2.17 \pm \\
0.01\end{array}$ & $\begin{array}{l}2.74 \pm \\
0.02\end{array}$ & $<001$ & $\begin{array}{l}2.42 \pm \\
0.01\end{array}$ & $\begin{array}{l}2.42 \pm \\
0.02\end{array}$ & $<001$ & $\begin{array}{l}2.19 \pm \\
0.01\end{array}$ & $2.76 \pm 0.01$ & $\begin{array}{l}< \\
0.001\end{array}$ \\
\hline $\begin{array}{l}\text { Vitamin } B 6 \\
(\mu \mathrm{m} / \mathrm{d})\end{array}$ & $\begin{array}{l}2.58 \pm \\
0.02\end{array}$ & $\begin{array}{l}2.47 \pm \\
0.03\end{array}$ & 0.03 & $\begin{array}{l}2.45 \pm \\
0.02\end{array}$ & $\begin{array}{l}2.68 \pm \\
0.02\end{array}$ & $<.001$ & $\begin{array}{l}2.36 \pm \\
0.02\end{array}$ & $\begin{array}{l}2.69 \pm \\
0.02\end{array}$ & $<.001$ & $\begin{array}{l}2.32 \pm \\
0.02\end{array}$ & $2.88 \pm 0.02$ & $<.001$ \\
\hline $\begin{array}{l}\text { Folic Acid } \\
(\mu \mathrm{m} / \mathrm{d})\end{array}$ & $\begin{array}{l}407.79 \\
\pm 4.27\end{array}$ & $\begin{array}{l}309.76 \\
\pm 4.95\end{array}$ & $\dot{0} 001$ & $\begin{array}{l}381.01 \\
\pm 4.18\end{array}$ & $\begin{array}{l}389.22 \\
\pm 4.65\end{array}$ & $<.001$ & $\begin{array}{l}364.65 \\
\pm 4.18\end{array}$ & $\begin{array}{l}418.47 \\
\pm 4.46\end{array}$ & $<.001$ & $\begin{array}{l}318.62 \\
\pm 3.91\end{array}$ & $\begin{array}{l}490.02 \pm \\
4.06\end{array}$ & $<.001$ \\
\hline $\begin{array}{l}\text { Vitamin B12 } \\
(\mu \mathrm{m} / \mathrm{d})\end{array}$ & $\begin{array}{l}6.73 \pm \\
0.15\end{array}$ & $\begin{array}{l}3.25 \pm \\
0.17\end{array}$ & $<.001$ & $\begin{array}{l}4.86 \pm \\
0.14\end{array}$ & $\begin{array}{l}9.29 \pm \\
0.16\end{array}$ & $<.001$ & $\begin{array}{l}5.98 \pm \\
0.14\end{array}$ & $\begin{array}{l}6.91 \pm \\
0.15\end{array}$ & $<.001$ & $\begin{array}{l}5.68 \pm \\
0.14\end{array}$ & $7.19 \pm 0.15$ & $\dot{0} .001$ \\
\hline $\begin{array}{l}\text { Magnesium } \\
\text { (mg/day) }\end{array}$ & $\begin{array}{l}364.56 \\
\pm 2.55\end{array}$ & $\begin{array}{l}279.82 \\
\pm 2.96\end{array}$ & $<.001$ & $\begin{array}{l}331.10 \\
\pm 2.52\end{array}$ & $\begin{array}{l}364.24 \\
\pm 2.81\end{array}$ & $<.001$ & $\begin{array}{l}315.68 \\
\pm 2.50\end{array}$ & $\begin{array}{l}376.36 \\
\pm 2.67\end{array}$ & $<.001$ & $\begin{array}{l}307.03 \\
\pm 2.39\end{array}$ & $\begin{array}{l}402.45 \pm \\
2.49\end{array}$ & $\begin{array}{l}<.001 \\
0\end{array}$ \\
\hline $\begin{array}{l}\text { Calcium } \\
\text { (mg/day) }\end{array}$ & $\begin{array}{l}1011.01 \\
\pm 9.02\end{array}$ & $\begin{array}{l}755.45 \\
\pm 10.45\end{array}$ & $<.001$ & $\begin{array}{l}911.54 \\
\pm 8.93\end{array}$ & $\begin{array}{l}1035.37 \\
\pm 9.94\end{array}$ & $\begin{array}{l}< \\
0.001\end{array}$ & $\begin{array}{l}959.18 \\
\pm 9.03\end{array}$ & $\begin{array}{l}994.37 \\
\pm 9.64\end{array}$ & $<001$ & $\begin{array}{l}862.64 \\
\pm 8.57\end{array}$ & $\begin{array}{l}1170.15 \pm \\
8.90\end{array}$ & $\begin{array}{l}<.001 \\
0.00\end{array}$ \\
\hline $\begin{array}{l}\text { Iron } \\
\text { (mg/day) }\end{array}$ & $\begin{array}{l}46.00 \pm \\
2.19\end{array}$ & $\begin{array}{l}32.24 \pm \\
2.55\end{array}$ & $<.001$ & $\begin{array}{l}45.62 \pm \\
2.12\end{array}$ & $\begin{array}{l}44.32 \pm \\
2.36\end{array}$ & 0.41 & $\begin{array}{l}36.79 \pm \\
2.13\end{array}$ & $\begin{array}{l}54.27 \pm \\
2.27\end{array}$ & $<.001$ & $\begin{array}{l}37.45 \pm \\
2.12\end{array}$ & $\begin{array}{l}48.13 \pm \\
2.21\end{array}$ & <. 001 \\
\hline \multicolumn{13}{|c|}{${ }^{1}$ Values are reported as Mean \pm standard Error (SE) } \\
\hline
\end{tabular}


Table 4

Comparison of depression, anxiety and stress score according to quintiles of dietary food patterns in crude and multivariable adjusted models.

\begin{tabular}{|c|c|c|c|c|c|c|c|c|c|}
\hline & \multicolumn{3}{|c|}{ Depression score } & \multicolumn{3}{|c|}{ Anxiety score } & \multicolumn{3}{|c|}{ Stress score } \\
\hline & Crude & Model $1^{2}$ & Model $2^{3}$ & Crude & Model 1 & Model 2 & Crude & Model 1 & Model 2 \\
\hline \multicolumn{10}{|c|}{ Factor 1: Sugar and Fats } \\
\hline Q1 & $\begin{array}{l}3.50 \pm \\
0.10\end{array}$ & $\begin{array}{l}3.44 \pm \\
0.10\end{array}$ & $\begin{array}{l}3.33 \pm \\
0.10\end{array}$ & $\begin{array}{l}3.33 \pm \\
0.09\end{array}$ & $\begin{array}{l}3.23 \pm \\
0.09\end{array}$ & $\begin{array}{l}3.05 \pm \\
0.10\end{array}$ & $\begin{array}{l}5.89 \pm \\
0.12\end{array}$ & $\begin{array}{l}5.92 \pm \\
0.12\end{array}$ & $\begin{array}{l}5.86 \pm \\
0.13\end{array}$ \\
\hline Q2 & $\begin{array}{l}3.36 \pm \\
0.10\end{array}$ & $\begin{array}{l}3.31 \pm \\
0.10\end{array}$ & $\begin{array}{l}3.28 \pm \\
0.10\end{array}$ & $\begin{array}{l}3.06 \pm \\
0.09\end{array}$ & $\begin{array}{l}2.94 \pm \\
0.09\end{array}$ & $\begin{array}{l}2.91 \pm \\
0.10\end{array}$ & $\begin{array}{l}5.81 \pm \\
0.12\end{array}$ & $\begin{array}{l}5.86 \pm \\
0.12\end{array}$ & $\begin{array}{l}5.84 \pm \\
0.13\end{array}$ \\
\hline Q3 & $\begin{array}{l}3.14 \pm \\
0.10\end{array}$ & $\begin{array}{l}3.13 \pm \\
0.10\end{array}$ & $\begin{array}{l}3.08 \pm \\
0.10\end{array}$ & $\begin{array}{l}2.72 \pm \\
0.09\end{array}$ & $\begin{array}{l}2.68 \pm \\
0.09\end{array}$ & $\begin{array}{l}2.62 \pm \\
0.09\end{array}$ & $\begin{array}{l}5.99 \pm \\
0.12\end{array}$ & $\begin{array}{l}6.04 \pm \\
0.12\end{array}$ & $\begin{array}{l}6.03 \pm \\
0.13\end{array}$ \\
\hline Q4 & $\begin{array}{l}3.24 \pm \\
0.10\end{array}$ & $\begin{array}{l}3.26 \pm \\
0.10\end{array}$ & $\begin{array}{l}3.25 \pm \\
0.10\end{array}$ & $\begin{array}{l}3.05 \pm \\
0.09\end{array}$ & $\begin{array}{l}3.09 \pm \\
0.09\end{array}$ & $\begin{array}{l}3.05 \pm \\
0.09\end{array}$ & $\begin{array}{l}6.04 \pm \\
0.12\end{array}$ & $\begin{array}{l}6.02 \pm \\
0.12\end{array}$ & $\begin{array}{l}6.05 \pm \\
0.12\end{array}$ \\
\hline Q5 & $\begin{array}{l}3.41 \pm \\
0.10\end{array}$ & $\begin{array}{l}3.48 \pm \\
0.11\end{array}$ & $\begin{array}{l}3.42 \pm \\
0.12\end{array}$ & $\begin{array}{l}2.81 \pm \\
0.09\end{array}$ & $\begin{array}{l}3.00 \pm \\
0.11\end{array}$ & $\begin{array}{l}2.94 \pm \\
0.11\end{array}$ & $\begin{array}{l}5.91 \pm \\
0.12\end{array}$ & $\begin{array}{l}5.81 \pm \\
0.14\end{array}$ & $\begin{array}{l}5.78 \pm \\
0.15\end{array}$ \\
\hline P-value & 0.08 & 0.12 & 0.27 & 0.00 & 0.00 & 0.01 & 0.73 & 0.67 & 0.49 \\
\hline \multicolumn{10}{|c|}{$\begin{array}{l}\text { Factor 2: Red meat and } \\
\text { Fish }\end{array}$} \\
\hline Q1 & $\begin{array}{l}3.50 \pm \\
0.10\end{array}$ & $\begin{array}{l}3.45 \pm \\
0.09\end{array}$ & $\begin{array}{l}3.34 \pm \\
0.10\end{array}$ & $\begin{array}{l}3.11 \pm \\
0.09\end{array}$ & $\begin{array}{l}3.06 \pm \\
0.09\end{array}$ & $\begin{array}{l}2.96 \pm \\
0.09\end{array}$ & $\begin{array}{l}5.94 \pm \\
0.12\end{array}$ & $\begin{array}{l}5.92 \pm \\
0.12\end{array}$ & $\begin{array}{l}5.92 \pm \\
0.12\end{array}$ \\
\hline Q2 & $\begin{array}{l}3.35 \pm \\
0.10\end{array}$ & $\begin{array}{l}3.30 \pm \\
0.10\end{array}$ & $\begin{array}{l}3.24 \pm \\
0.10\end{array}$ & $\begin{array}{l}3.02 \pm \\
0.09\end{array}$ & $\begin{array}{l}2.94 \pm \\
0.09\end{array}$ & $\begin{array}{l}2.84 \pm \\
0.10\end{array}$ & $\begin{array}{l}5.88 \pm \\
0.12\end{array}$ & $\begin{array}{l}5.87 \pm \\
0.12\end{array}$ & $\begin{array}{l}5.83 \pm \\
0.13\end{array}$ \\
\hline Q3 & $\begin{array}{l}3.16 \pm \\
0.09\end{array}$ & $\begin{array}{l}3.13 \pm \\
0.10\end{array}$ & $\begin{array}{l}3.14 \pm \\
0.10\end{array}$ & $\begin{array}{l}3.08 \pm \\
0.09\end{array}$ & $\begin{array}{l}3.01 \pm \\
0.09\end{array}$ & $\begin{array}{l}2.98 \pm \\
0.09\end{array}$ & $\begin{array}{l}5.78 \pm \\
0.12\end{array}$ & $\begin{array}{l}5.77 \pm \\
0.12\end{array}$ & $\begin{array}{l}5.79 \pm \\
0.13\end{array}$ \\
\hline Q4 & $\begin{array}{l}3.22 \pm \\
0.10\end{array}$ & $\begin{array}{l}3.22 \pm \\
0.10\end{array}$ & $\begin{array}{l}3.17 \pm \\
0.10\end{array}$ & $\begin{array}{l}3.02 \pm \\
0.09\end{array}$ & $\begin{array}{l}3.03 \pm \\
0.09\end{array}$ & $\begin{array}{l}2.95 \pm \\
0.09\end{array}$ & $\begin{array}{l}5.75 \pm \\
0.12\end{array}$ & $\begin{array}{l}5.75 \pm \\
0.12\end{array}$ & $\begin{array}{l}5.77 \pm \\
0.13\end{array}$ \\
\hline Q5 & $\begin{array}{l}3.42 \pm \\
0.10\end{array}$ & $\begin{array}{l}3.51 \pm \\
0.11\end{array}$ & $\begin{array}{l}3.48 \pm \\
0.11\end{array}$ & $\begin{array}{l}2.74 \pm \\
0.09\end{array}$ & $\begin{array}{l}2.88 \pm \\
0.10\end{array}$ & $\begin{array}{l}2.83 \pm \\
0.10\end{array}$ & $\begin{array}{l}6.29 \pm \\
0.12\end{array}$ & $\begin{array}{l}6.34 \pm \\
0.13\end{array}$ & $\begin{array}{l}6.26 \pm \\
0.14\end{array}$ \\
\hline P-value & 0.10 & 0.06 & 0.19 & 0.04 & 0.70 & 0.72 & 0.01 & 0.01 & 0.10 \\
\hline \multicolumn{10}{|c|}{ Factor 3: Fruits } \\
\hline Q1 & $\begin{array}{l}3.60 \pm \\
0.10\end{array}$ & $\begin{array}{l}3.62 \pm \\
0.10\end{array}$ & $\begin{array}{l}3.52 \pm \\
0.10\end{array}$ & $\begin{array}{l}3.22 \pm \\
0.09\end{array}$ & $\begin{array}{l}3.24 \pm \\
0.09\end{array}$ & $\begin{array}{l}3.13 \pm \\
0.09\end{array}$ & $\begin{array}{l}6.14 \pm \\
0.12\end{array}$ & $\begin{array}{l}6.17 \pm \\
0.12\end{array}$ & $\begin{array}{l}6.09 \pm \\
0.12\end{array}$ \\
\hline Q2 & $\begin{array}{l}3.43 \pm \\
0.10\end{array}$ & $\begin{array}{l}3.43 \pm \\
0.10\end{array}$ & $\begin{array}{l}3.31 \pm \\
0.10\end{array}$ & $\begin{array}{l}3.09 \pm \\
0.09\end{array}$ & $\begin{array}{l}3.01 \pm \\
0.09\end{array}$ & $\begin{array}{l}2.91 \pm \\
0.10\end{array}$ & $\begin{array}{l}5.84 \pm \\
0.12\end{array}$ & $\begin{array}{l}5.86 \pm \\
0.12\end{array}$ & $\begin{array}{l}5.73 \pm \\
0.13\end{array}$ \\
\hline Q3 & $\begin{array}{l}3.18 \pm \\
0.10\end{array}$ & $\begin{array}{l}3.17 \pm \\
0.10\end{array}$ & $\begin{array}{l}3.14 \pm \\
0.10\end{array}$ & $\begin{array}{l}2.91 \pm \\
0.09\end{array}$ & $\begin{array}{l}2.84 \pm \\
0.09\end{array}$ & $\begin{array}{l}2.77 \pm \\
0.09\end{array}$ & $\begin{array}{l}5.68 \pm \\
0.12\end{array}$ & $\begin{array}{l}5.68 \pm \\
0.12\end{array}$ & $\begin{array}{l}5.67 \pm \\
0.13\end{array}$ \\
\hline Q4 & $\begin{array}{l}3.46 \pm \\
0.10\end{array}$ & $\begin{array}{l}3.44 \pm \\
0.09\end{array}$ & $\begin{array}{l}3.41 \pm \\
0.10\end{array}$ & $\begin{array}{l}3.06 \pm \\
0.09\end{array}$ & $\begin{array}{l}3.03 \pm \\
0.09\end{array}$ & $\begin{array}{l}2.98 \pm \\
0.09\end{array}$ & $\begin{array}{l}6.01 \pm \\
0.12\end{array}$ & $\begin{array}{l}6.01 \pm \\
0.12\end{array}$ & $\begin{array}{l}6.03 \pm \\
0.12\end{array}$ \\
\hline Q5 & $\begin{array}{l}2.99 \pm \\
0.10\end{array}$ & $\begin{array}{l}2.96 \pm \\
0.10\end{array}$ & $\begin{array}{l}2.98 \pm \\
0.11\end{array}$ & $\begin{array}{l}2.70 \pm \\
0.09\end{array}$ & $\begin{array}{l}2.81 \pm \\
0.10\end{array}$ & $\begin{array}{l}2.78 \pm \\
0.10\end{array}$ & $\begin{array}{l}5.97 \pm \\
0.12\end{array}$ & $\begin{array}{l}5.93 \pm \\
0.13\end{array}$ & $\begin{array}{l}6.04 \pm \\
0.13\end{array}$ \\
\hline P-value & $<0.001$ & $<0.001$ & $<0.001$ & $<0.001$ & 0.01 & 0.05 & 0.09 & 0.08 & 0.08 \\
\hline \multicolumn{10}{|c|}{ Factor 4: Vegetables } \\
\hline Q1 & $\begin{array}{l}3.53 \pm \\
0.10\end{array}$ & $\begin{array}{l}3.53 \pm \\
0.09\end{array}$ & $\begin{array}{l}3.44 \pm \\
0.10\end{array}$ & $\begin{array}{l}3.15 \pm \\
0.09\end{array}$ & $\begin{array}{l}3.17 \pm \\
0.09\end{array}$ & $\begin{array}{l}3.09 \pm \\
0.09\end{array}$ & $\begin{array}{l}5.96 \pm \\
0.12\end{array}$ & $\begin{array}{l}5.96 \pm \\
0.12\end{array}$ & $\begin{array}{l}5.90 \pm \\
0.13\end{array}$ \\
\hline Q2 & $\begin{array}{l}3.19 \pm \\
0.10\end{array}$ & $\begin{array}{l}3.14 \pm \\
0.10\end{array}$ & $\begin{array}{l}3.00 \pm \\
0.10\end{array}$ & $\begin{array}{l}2.92 \pm \\
0.09\end{array}$ & $\begin{array}{l}2.81 \pm \\
0.09\end{array}$ & $\begin{array}{l}2.67 \pm \\
0.09\end{array}$ & $\begin{array}{l}5.81 \pm \\
0.12\end{array}$ & $\begin{array}{l}5.81 \pm \\
0.12\end{array}$ & $\begin{array}{l}5.70 \pm \\
0.13\end{array}$ \\
\hline Q3 & $\begin{array}{l}3.14 \pm \\
0.10\end{array}$ & $\begin{array}{l}3.10 \pm \\
0.10\end{array}$ & $\begin{array}{l}3.10 \pm \\
0.10\end{array}$ & $\begin{array}{l}2.77 \pm \\
0.09\end{array}$ & $\begin{array}{l}2.67 \pm \\
0.09\end{array}$ & $\begin{array}{l}2.64 \pm \\
0.09\end{array}$ & $\begin{array}{l}5.68 \pm \\
0.12\end{array}$ & $\begin{array}{l}5.66 \pm \\
0.12\end{array}$ & $\begin{array}{l}5.69 \pm \\
0.13\end{array}$ \\
\hline
\end{tabular}

${ }^{1}$ All analyses were conducted using analysis of covariance and values are reported as Mean \pm Standard Error (SE).

${ }^{2}$ Adjusted for age, sex and total energy.

${ }^{3}$ Adjusted for age, sex, total energy, BMI, physical activity, marital status, smoking status, job status, education status, home ownership, diabetes and hypertension. 


\begin{tabular}{|c|c|c|c|c|c|c|c|c|c|}
\hline & \multicolumn{3}{|c|}{ Depression score } & \multicolumn{3}{|c|}{ Anxiety score } & \multicolumn{3}{|c|}{ Stress score } \\
\hline & Crude & Model $1^{2}$ & Model $2^{3}$ & Crude & Model 1 & Model 2 & Crude & Model 1 & Model 2 \\
\hline Q4 & $\begin{array}{l}3.30 \pm \\
0.09\end{array}$ & $\begin{array}{l}3.31 \pm \\
0.09\end{array}$ & $\begin{array}{l}3.31 \pm \\
0.10\end{array}$ & $\begin{array}{l}2.95 \pm \\
0.09\end{array}$ & $\begin{array}{l}2.95 \pm \\
0.09\end{array}$ & $\begin{array}{l}2.93 \pm \\
0.09\end{array}$ & $\begin{array}{l}5.99 \pm \\
0.12\end{array}$ & $\begin{array}{l}6.01 \pm \\
0.12\end{array}$ & $\begin{array}{l}6.06 \pm \\
0.12\end{array}$ \\
\hline Q5 & $\begin{array}{l}3.49 \pm \\
0.10\end{array}$ & $\begin{array}{l}3.53 \pm \\
0.10\end{array}$ & $\begin{array}{l}3.50 \pm \\
0.10\end{array}$ & $\begin{array}{l}3.18 \pm \\
0.09\end{array}$ & $\begin{array}{l}3.32 \pm \\
0.09\end{array}$ & $\begin{array}{l}3.22 \pm \\
0.10\end{array}$ & $\begin{array}{l}6.19 \pm \\
0.12\end{array}$ & $\begin{array}{l}6.21 \pm \\
0.12\end{array}$ & $\begin{array}{l}6.21 \pm \\
0.13\end{array}$ \\
\hline P-value & $<0.001$ & $<0.001$ & $<0.001$ & 0.01 & $<0.001$ & $<0.001$ & 0.04 & 0.03 & 0.02 \\
\hline \multicolumn{10}{|c|}{${ }^{1}$ All analyses were conducted using analysis of covariance and values are reported as Mean \pm Standard Error (SE). } \\
\hline \multicolumn{10}{|c|}{${ }^{2}$ Adjusted for age, sex and total energy. } \\
\hline
\end{tabular}


Table 5

The likelihood for developing severe depression, anxiety and stress according to quintile of dietary food patterns.

\begin{tabular}{|c|c|c|c|c|c|c|c|c|c|}
\hline & \multicolumn{3}{|c|}{ Severe Depression } & \multicolumn{3}{|c|}{ Severe anxiety } & \multicolumn{3}{|c|}{ Severe Stress } \\
\hline & Crude & Model $1^{2}$ & Model $2^{3}$ & Crude & Model 1 & Model 2 & Crude & Model 1 & Model 2 \\
\hline \multicolumn{10}{|c|}{$\begin{array}{l}\text { Factor 1: Sugar } \\
\text { and Fats }\end{array}$} \\
\hline Q1 & 1 & 1 & 1 & 1 & 1 & 1 & 1 & 1 & 1 \\
\hline Q2 & $\begin{array}{l}0.83 \\
(0.64- \\
1.10)\end{array}$ & $\begin{array}{l}0.82 \\
(0.64- \\
1.06)\end{array}$ & $\begin{array}{l}0.88 \\
(0.66- \\
1.16)\end{array}$ & $\begin{array}{l}0.84 \\
(0.67- \\
1.06)\end{array}$ & $\begin{array}{l}0.83 \\
(0.66- \\
1.05)\end{array}$ & $\begin{array}{l}0.90 \\
(0.70- \\
1.17)\end{array}$ & $\begin{array}{l}1.20 \\
(0.81- \\
1.77)\end{array}$ & $\begin{array}{l}1.17 \\
(0.80- \\
1.73)\end{array}$ & $\begin{array}{l}1.30(0.85- \\
2.00)\end{array}$ \\
\hline Q3 & $\begin{array}{l}0.70 \\
(0.54- \\
0.92)\end{array}$ & $\begin{array}{l}0.71 \\
(0.55- \\
0.93)\end{array}$ & $\begin{array}{l}0.72 \\
(0.54- \\
0.97)\end{array}$ & $\begin{array}{l}0.77 \\
(0.60- \\
0.98)\end{array}$ & $\begin{array}{l}0.78 \\
(0.61- \\
0.99)\end{array}$ & $\begin{array}{l}0.81 \\
(0.62- \\
1.06)\end{array}$ & $\begin{array}{l}0.93 \\
(0.62- \\
1.40)\end{array}$ & $\begin{array}{l}0.94 \\
(0.62- \\
1.42)\end{array}$ & $\begin{array}{l}1.01 \\
(0.64- \\
1.58)\end{array}$ \\
\hline Q4 & $\begin{array}{l}0.66 \\
(0.50- \\
0.87)\end{array}$ & $\begin{array}{l}0.69 \\
(0.52- \\
0.91)\end{array}$ & $\begin{array}{l}0.76 \\
(0.56- \\
1.03)\end{array}$ & $\begin{array}{l}0.80 \\
(0.63- \\
1.01)\end{array}$ & $\begin{array}{l}0.82 \\
(0.64- \\
1.04)\end{array}$ & $\begin{array}{l}0.90 \\
(0.69- \\
1.18)\end{array}$ & $\begin{array}{l}0.81 \\
(0.53- \\
1.24)\end{array}$ & $\begin{array}{l}0.82 \\
(0.53- \\
1.27)\end{array}$ & $\begin{array}{l}0.91 \\
(0.56- \\
1.47)\end{array}$ \\
\hline Q5 & $\begin{array}{l}0.83 \\
(0.64- \\
1.09)\end{array}$ & $\begin{array}{l}0.97 \\
(0.71- \\
1.32)\end{array}$ & $\begin{array}{l}1.08 \\
(0.77- \\
1.52)\end{array}$ & $\begin{array}{l}0.91 \\
(0.72- \\
1.14)\end{array}$ & $\begin{array}{l}1.00 \\
(0.76- \\
1.32)\end{array}$ & $\begin{array}{l}1.12 \\
(0.83- \\
1.52)\end{array}$ & $\begin{array}{l}0.92 \\
(0.61- \\
1.39)\end{array}$ & $\begin{array}{l}1.00 \\
(0.61- \\
1.63)\end{array}$ & $\begin{array}{l}1.06 \\
(0.62- \\
1.81)\end{array}$ \\
\hline P-trend & 0.043 & 0.164 & 0.544 & 0.345 & 0.530 & 0.863 & 0.233 & 0.460 & 0.661 \\
\hline \multicolumn{10}{|c|}{$\begin{array}{l}\text { Factor 2: Red meat } \\
\text { and Fish }\end{array}$} \\
\hline Q1 & 1 & 1 & 1 & 1 & 1 & 1 & 1 & 1 & 1 \\
\hline Q2 & $\begin{array}{l}0.83 \\
(0.64- \\
1.10)\end{array}$ & $\begin{array}{l}0.80 \\
(0.61- \\
1.04)\end{array}$ & $\begin{array}{l}0.83 \\
(0.62- \\
1.11)\end{array}$ & $\begin{array}{l}0.81 \\
(0.64- \\
1.02)\end{array}$ & $\begin{array}{l}0.78 \\
(0.62- \\
0.99)\end{array}$ & $\begin{array}{l}0.81 \\
(0.62- \\
1.05)\end{array}$ & $\begin{array}{l}1.15 \\
(0.78- \\
1.70)\end{array}$ & $\begin{array}{l}1.11 \\
(0.75- \\
1.65)\end{array}$ & $\begin{array}{l}1.04 \\
(0.68- \\
1.59)\end{array}$ \\
\hline Q3 & $\begin{array}{l}0.72 \\
(0.56- \\
0.95)\end{array}$ & $\begin{array}{l}0.70 \\
(0.53- \\
0.92)\end{array}$ & $\begin{array}{l}0.75 \\
(0.56- \\
1.01)\end{array}$ & $\begin{array}{l}0.71 \\
(0.56- \\
0.90)\end{array}$ & $\begin{array}{l}0.69 \\
(0.54- \\
0.88)\end{array}$ & $\begin{array}{l}0.78 \\
(0.60- \\
1.01)\end{array}$ & $\begin{array}{l}0.72 \\
(0.47- \\
1.12)\end{array}$ & $\begin{array}{l}0.70 \\
(0.45- \\
1.09)\end{array}$ & $\begin{array}{l}0.66 \\
(0.41- \\
1.05)\end{array}$ \\
\hline Q4 & $\begin{array}{l}0.85 \\
(0.66- \\
1.11)\end{array}$ & $\begin{array}{l}0.86 \\
(0.66- \\
1.12)\end{array}$ & $\begin{array}{l}0.92 \\
(0.69- \\
1.23)\end{array}$ & $\begin{array}{l}0.79(0.62- \\
1.00)\end{array}$ & $\begin{array}{l}0.79(0.62- \\
1.00)\end{array}$ & $\begin{array}{l}0.85 \\
(0.66- \\
1.11)\end{array}$ & $\begin{array}{l}1.08 \\
(0.72- \\
1.60)\end{array}$ & $\begin{array}{l}1.06 \\
(0.71- \\
1.58)\end{array}$ & $\begin{array}{l}0.97 \\
(0.63- \\
1.50)\end{array}$ \\
\hline Q5 & $\begin{array}{l}0.92 \\
(0.71- \\
1.19)\end{array}$ & $\begin{array}{l}1.06 \\
(0.80- \\
1.40)\end{array}$ & $\begin{array}{l}1.15 \\
(0.85- \\
1.55)\end{array}$ & $\begin{array}{l}0.96 \\
(0.77- \\
1.20)\end{array}$ & $\begin{array}{l}1.06 \\
(0.83- \\
1.35)\end{array}$ & $\begin{array}{l}1.17 \\
(0.90- \\
1.53)\end{array}$ & $\begin{array}{l}0.92 \\
(0.61- \\
1.40)\end{array}$ & $\begin{array}{l}1.02 \\
(0.66- \\
1.58)\end{array}$ & $\begin{array}{l}0.94 \\
(0.59- \\
1.51)\end{array}$ \\
\hline P-trend & 0.609 & 0.698 & 0.008 & 0.664 & 0.214 & 0.062 & 0.607 & 0.851 & 0.605 \\
\hline \multicolumn{10}{|c|}{ Factor 3: Fruits } \\
\hline Q1 & 1 & 1 & 1 & 1 & 1 & 1 & 1 & 1 & 1 \\
\hline Q2 & $\begin{array}{l}0.93 \\
(0.72- \\
1.21)\end{array}$ & $\begin{array}{l}0.93 \\
(0.72- \\
1.21)\end{array}$ & $\begin{array}{l}0.92 \\
(0.69- \\
1.23)\end{array}$ & $\begin{array}{l}0.92 \\
(0.73- \\
1.15)\end{array}$ & $\begin{array}{l}0.92 \\
(0.73- \\
1.16)\end{array}$ & $\begin{array}{l}0.88 \\
(0.68- \\
1.14)\end{array}$ & $\begin{array}{l}0.68 \\
(0.47- \\
0.98)\end{array}$ & $\begin{array}{l}0.66 \\
(0.45- \\
0.97)\end{array}$ & $\begin{array}{l}0.65(0.42- \\
1.00)\end{array}$ \\
\hline Q3 & $\begin{array}{l}0.78 \\
(0.60- \\
1.01)\end{array}$ & $\begin{array}{l}0.77 \\
(0.59- \\
1.02)\end{array}$ & $\begin{array}{l}0.84 \\
(0.62- \\
1.12)\end{array}$ & $\begin{array}{l}0.74 \\
(0.59- \\
0.94)\end{array}$ & $\begin{array}{l}0.75 \\
(0.59- \\
0.96)\end{array}$ & $\begin{array}{l}0.78 \\
(0.60- \\
1.01)\end{array}$ & $\begin{array}{l}0.50 \\
(0.33- \\
0.75)\end{array}$ & $\begin{array}{l}0.49 \\
(0.32- \\
0.74)\end{array}$ & $\begin{array}{l}0.55 \\
(0.35- \\
0.85)\end{array}$ \\
\hline Q4 & $\begin{array}{l}1.02 \\
(0.80- \\
1.31)\end{array}$ & $\begin{array}{l}1.02 \\
(0.79- \\
1.31)\end{array}$ & $\begin{array}{l}1.04 \\
(0.79- \\
1.37)\end{array}$ & $\begin{array}{l}0.90 \\
(0.72- \\
1.14)\end{array}$ & $\begin{array}{l}0.90 \\
(0.72- \\
1.13)\end{array}$ & $\begin{array}{l}0.91 \\
(0.71- \\
1.17)\end{array}$ & $\begin{array}{l}0.69(0.48- \\
1.00)\end{array}$ & $\begin{array}{l}0.68 \\
(0.47- \\
0.99)\end{array}$ & $\begin{array}{l}0.74 \\
(0.50- \\
1.11)\end{array}$ \\
\hline Q5 & $\begin{array}{l}0.61 \\
(0.45- \\
0.81)\end{array}$ & $\begin{array}{l}0.62 \\
(0.47- \\
0.84)\end{array}$ & $\begin{array}{l}0.63 \\
(0.46- \\
0.87)\end{array}$ & $\begin{array}{l}0.64 \\
(0.50- \\
0.80)\end{array}$ & $\begin{array}{l}0.63 \\
(0.49- \\
0.82)\end{array}$ & $\begin{array}{l}0.64 \\
(0.48- \\
0.84)\end{array}$ & $\begin{array}{l}0.45 \\
(0.30- \\
0.68)\end{array}$ & $\begin{array}{l}0.47 \\
(0.30- \\
0.72)\end{array}$ & $\begin{array}{l}0.46 \\
(0.29- \\
0.74)\end{array}$ \\
\hline P-trend & 0.008 & 0.019 & 0.057 & 0.001 & 0.002 & 0.007 & 0.001 & 0.839 & 0.081 \\
\hline \multicolumn{10}{|c|}{$\begin{array}{l}\text { Factor 4: } \\
\text { Vegetables }\end{array}$} \\
\hline Q1 & 1 & 1 & 1 & 1 & 1 & 1 & 1 & 1 & 1 \\
\hline Q2 & $\begin{array}{l}0.91 \\
(0.70- \\
1.19)\end{array}$ & $\begin{array}{l}0.87 \\
(0.66- \\
1.13)\end{array}$ & $\begin{array}{l}0.82 \\
(0.61- \\
1.11)\end{array}$ & $\begin{array}{l}0.84 \\
(0.66- \\
1.06)\end{array}$ & $\begin{array}{l}0.82 \\
(0.64- \\
1.04)\end{array}$ & $\begin{array}{l}0.81 \\
(0.62- \\
1.06)\end{array}$ & $\begin{array}{l}0.82 \\
(0.54- \\
1.22)\end{array}$ & $\begin{array}{l}0.77 \\
(0.51- \\
1.16)\end{array}$ & $\begin{array}{l}0.67 \\
(0.43- \\
1.06)\end{array}$ \\
\hline
\end{tabular}




\begin{tabular}{|c|c|c|c|c|c|c|c|c|c|}
\hline & \multicolumn{3}{|c|}{ Severe Depression } & \multicolumn{3}{|c|}{ Severe anxiety } & \multicolumn{3}{|c|}{ Severe Stress } \\
\hline & Crude & Model $1^{2}$ & Model $2^{3}$ & Crude & Model 1 & Model 2 & Crude & Model 1 & Model 2 \\
\hline Q3 & $\begin{array}{l}0.87 \\
(0.66- \\
1.13)\end{array}$ & $\begin{array}{l}0.83 \\
(0.63- \\
1.09)\end{array}$ & $\begin{array}{l}0.87 \\
(0.65- \\
1.17)\end{array}$ & $\begin{array}{l}0.86 \\
(0.68- \\
1.09)\end{array}$ & $\begin{array}{l}0.85 \\
(0.67- \\
1.08)\end{array}$ & $\begin{array}{l}0.90 \\
(0.69- \\
1.17)\end{array}$ & $\begin{array}{l}0.88 \\
(0.59- \\
1.32)\end{array}$ & $\begin{array}{l}0.84 \\
(0.56- \\
1.26)\end{array}$ & $\begin{array}{l}0.82 \\
(0.53- \\
1.28)\end{array}$ \\
\hline Q4 & $\begin{array}{l}0.90 \\
(0.69- \\
1.16)\end{array}$ & $\begin{array}{l}0.88 \\
(0.68- \\
1.15)\end{array}$ & $\begin{array}{l}0.92 \\
(0.69- \\
1.22)\end{array}$ & $\begin{array}{l}0.94 \\
(0.74- \\
1.18)\end{array}$ & $\begin{array}{l}0.93 \\
(0.74- \\
1.18)\end{array}$ & $\begin{array}{l}0.95 \\
(0.74- \\
1.23)\end{array}$ & $\begin{array}{l}0.90 \\
(0.61- \\
1.33)\end{array}$ & $\begin{array}{l}0.89 \\
(0.60- \\
1.33)\end{array}$ & $\begin{array}{l}0.92 \\
(0.60- \\
1.40)\end{array}$ \\
\hline Q5 & $\begin{array}{l}0.95 \\
(0.73- \\
1.24)\end{array}$ & $\begin{array}{l}1.00 \\
(0.77- \\
1.31)\end{array}$ & $\begin{array}{l}1.00 \\
(0.75- \\
1.34)\end{array}$ & $\begin{array}{l}0.98 \\
(0.77- \\
1.23)\end{array}$ & $\begin{array}{l}1.01 \\
(0.80- \\
1.28)\end{array}$ & $\begin{array}{l}1.01 \\
(0.78- \\
1.30)\end{array}$ & $\begin{array}{l}0.82 \\
(0.55- \\
1.23)\end{array}$ & $\begin{array}{l}0.85 \\
(0.57- \\
1.29)\end{array}$ & $\begin{array}{l}0.87 \\
(0.56- \\
1.35)\end{array}$ \\
\hline P-trend & 0.705 & 0.965 & 0.812 & 0.831 & 0.666 & 0.615 & 0.493 & 0.774 & 0.074 \\
\hline
\end{tabular}

